\title{
Globule Dosage Form
}

National Cancer Institute

\section{Source}

National Cancer Institute. Globule Dosage Form. NCI Thesaurus. Code C42937.

A solid composed of sucrose, lactose or other polysaccharides formed into small globular pellets impregnated with active and/or inert ing redient(s). 